\title{
PENERAPAN EVALUASI PEMBELAJARAN BERBASIS MEDIA SOSIAL PADA MATERI NASIONALISME PELATIHAN DASAR CALON PEGAWAI NEGERI SIPIL KABUPATEN HALMAHERA SELATAN
}

\section{THE APPLICATION OF SOCIAL MEDIA BASED LEARNING EVALUATION ON NATIONALISM MATERIALS OF BASIC TRAINING CANDIDATE CIVIL SERVANTS IN SOUTH HALMAHERA REGENCY}

\author{
Taufik Z. Karim \\ Badan Pengembangan Sumber Daya Manusia Provinsi Maluku Utara \\ J1. Raya Empat Puluh Kel. Guraping, Kec. Oba Utara, Maluku Utara \\ E-mail : taufikzkwidyaiswara@gmail.com
}

Naskah diterima tanggal 15 Juni 2020. Naskah direvisi tanggal 30 Juni 2020. Naskah disetujui tanggal 14 Juli 2020

\begin{abstract}
Abstrak
Penelitian ini bertujuan untuk menemukan pertama, proses atau tahapan penerapan evaluasi pembelajaran berbasis media sosial, dan kedua mengetahui implementasi pemanfaatan teknologi dalam evaluasi pembelajaran berbasis media sosial. Metode penelitian yang digunakan dalam penelitian ini adalah metode kuantitatif. Sampel yang digunakan dalam penelitian adalah peserta Pelatihan Dasar Calon Pegawai Negeri Sipil Kabupaten Halmahera Selatan Tahun 2020 sebanyak 30 responden. Teknik pengumpulan data yang digunakan dalam penelitian adalah kajian pustaka dan penyebaran kuisioner. Teknik analisis data dilakukan dengan metode statistik deskriptif. Hasil penelitian diketahui bahwa, pertama ditemukan 8 (delapan) tahapan atau proses penerapan evaluasi pembelajaran. Kedua, implementasi pemanfataan teknologi dalam evaluasi pembelajaran seperti Kahoot.it dan facebook memberikan dampak positif dalam proses pembelajaran. Dimana proses evaluasi pembelajaran dinilai sangat kreatif dan inovatif.
\end{abstract}

Kata Kunci: evaluasi pembelajaran, media sosial, pemanfaatan teknologi

\begin{abstract}
This study aims to find first, the process or stages of the application of social media-based learning evaluation, and secondly, the implementation of technology use in the evaluation of social media-based learning. The sample used in this study was 30 participants of Basic Civil Servant Candidates in South Halmahera Regency in 2020. Data collection techniques used in research are literature review and questionnaire distribution. The data analysis technique was conducted using descriptive statistical methods. The results of the study note that, first found 8 (eight) stages or the process of applying learning evaluation. Second, the use of technology in evaluating learning such as Kahoot.it and Facebook has a positive impact on the learning process. Where the learning evaluation process is considered to be very creative and innovative.
\end{abstract}

Keywords: learning evaluation, social media, and technology utilization.

\section{PENDAHULUAN}

\section{Latar Belakang}

Perkembangan teknologi informasi yang semakin maju secara tidak langsung menggiring dunia pelatihan menjadi melek teknologi. Selain itu, perkembangan teknologi informasi tentu membuka peluang-peluang baru pertukaran pengetahuan dapat terlaksana walaupun terkendala oleh jarak, waktu dan tempat (Mao, Liu, Zhang, \& Deng, 2016). Menurut Ngafifi (2014) kemajuan teknologi merupakan suatu hal yang searah 
dengan perkembangan ilmu pengetahuan, yang mempunyai dampak negatif maupun positif di dalamnya. Salah satu perkembangan teknologi informasi yakni internet dengan fasilitas media sosial. Media sosial dapat dipercaya sebagai sebuah tool atau alat bantu yang memberikan potensi luar biasa bagi organisasi dalam meningkatkan performan perusahaan (Hanna, Rohm, \& Crittenden, 2011). Menurut Hemsley \& Mason (2013), Media Sosial memungkinkan terselenggaranya interaksi, komunikasi, dan kolabaroasi diantara pengguana secara efektif, cepat, tepat dan relatif murah. Media sosial adalah saluran atau sarana pergaulan sosial secara online. Para pengguna media sosial bisa berkomunikasi, berinteraksi, saling kirim pesan, dan saling berbagi, dan membangun jaringan.

Media sosial selain digunakan untuk keperluan bersosialisasi, dapat dimanfaatkan juga sebagai media pembelajaran, karena media pembelajaran selalu berkembang sejalan dengan perkembangan ilmu dan teknologi. Menurut Rivai (2007), media sangat berguna dalam pembelajaran, karena media pembelajaran dapat meningkatkan proses belajar peserta didik dalam pengajaran yang pada saatnya diharapkan dapat meningkatkan hasil belajar yang dicapainya.

Menurut Nurseto dalam Fidian (2017) Peranan media pembelajaran semakin penting, karena kegiatan pembelajaran sekarang dituntut dan menekankan pada keterampilan proses dan active learning. Sehingga dengan adanya media pembelajaran, proses pembelajaran akan lebih mudah diterima oleh peserta didik dan dapat meningkatkan hasil belajar.

Namun, berdasarkan hasil evaluasi penilaian Widyaiswara BPSDM Provinsi Maluku Utara Tahun 2017 ditemukan bahwa penggunaan metode dan sistematika penyajian mendapatkan nilai terendah. Maka direkomendasikan perlu meningkatkan kemampuan penggunaan metode dan penyusunan sistematika pembelajaran di kelas. Oleh karena itu, perlu adanya perhatian utama pada aspek metode dan sistematika penyajian pembelajaran di kelas, dalam artian bahwa Widyaiswara dituntut melaksanakan pembelajaran yang kreatif dan kontekstual atau disesuaikan dengan perkembangan zaman yang serba digital.

Melihat fenomena tersebut, maka penulis berupaya mencari terobosan baru menjawab tuntutan tersebut. Hal ini penulis lakukan sebagai tanggungjawab seorang Widyaiswara yang sering memberikan materi dalam Pelatihan Dasar (Latsar) Calon Pegawai Negeri Sipil (CPNS).

\section{Rumusan Masalah}

Berdasarkan latar belakang yang telah diuraikan di atas, maka menjadi rumusan masalah dalam penelitian adalah :

1. Bagaimana proses atau tahapan penerapan evaluasi pembelajaran mata pelatihan nasionalisme berbasis media sosial?

2. Bagaimana implementasi pemanfaatan tekonologi dalam evaluasi pembelajaran?

\section{Tujuan dan manfaat}

Tujuan dan manfaat melakukan evaluasi pembelajaran berbasis media sosial adalah :

1. Mengetahui proses atau tahapan penerapan evaluasi pembelajaran,

2. Mengetahui implementasi pemanfaatan teknologi dalam evaluasi pembelajaran. Secara umum tujuan dan manfaat yang diharapkan adalah widyaiswara dan peserta pelatihan mampu beradaptasi dengan sistem pembelajaran zaman revolusi industri 4.0 diantaranya e-learning, blended learning maupun distance learning.

\section{TINJAUAN PUSTAKA}

\section{Pengertian Media Sosial}

Berbicara media sosial sebenarnya tidak sebatas beberapa jejaring sosial seperti Facebook, Twitter ataupun Instagram saja. Dalam istilah non teknologi, media sosial dapat 
diterjemahkan sebagai sebagai cara orang bertukar ide, konten, pemikiran dan hubungan secara online (Scoot, dalam Pakuningjati, 2015). Sedangkan menurut Philip Kotler dan Kevin Keller (2012) media sosial adalah sarana bagi pelanggan untuk berbagai informasi teks, gambar, video dan audio dengan satu sama lain dengan organisasi dan sebaliknya.

Pengertian media sosial menurut Antony Mayfield (2008) adalah media yang usernya mudah berpartisipasi, berbagi dan menciptakan peran, khususnya blog, jejaring sosial, wiki/ensiklopedia online, forum-forum maya, termasuk virtual worlds (dengan avatar/karakter 3D).

Andreas Kaplan dan Michael Haenlein (2010) mendefinisikan media sosial sebagai sebuah kelompok aplikasi berbasis internet yang membangun di atas dasar ideologi dan teknologi Web 2.0, dan yang memungkinkan penciptaan dan pertukaran konten yang dibuat pengguna.

Beberapa pengertian diatas tentang media sosial maka dapat disimpulkan definisi operasioanl media sosial adalah proses kegiatan saling berbagai konten seperti informasi teks, gambar, video dan audio dengan sebuah aplikasi online.

\section{Jenis dan Ciri Media Sosial}

Berkembangnya situs media sosial sangat menguntungkan banyak orang untuk saling berinteraksi dengan mudah dan dengan ongkos yang murah ketimbang memakai telepon. Dampak positif yang lain dari adanya situs media sosial adalah percepatan penyebaran informasi.

Menurut Tim Pusat Humas Kementerian Perdagangan RI, Panduan Optimalisasi Media Sosial Untuk Kemantrian Perdagangan RI (2014), menjelaskan pada dasarnya media sosial dapat dibagi menjadi enam jenis, diantaranya:

1.Proyek kolaborasi website, di mana usernya diizinkan untuk dapat mengubah, menambah, atau pun membuang kontenkonten yang termuat di website tersebut, seperti Wikipedia.

2. Blog dan microblog, di mana user mendapat kebebasan dalam mengungkapkan suatu hal di blog itu, seperti perasaan, pengalaman, pernyataan, sampai kritikan terhadap suatu hal, seperti Twitter.

3. Konten atau isi, di mana para user di website ini saling membagikan kontenkonten multimedia, seperti ebook, video, foto, gambar, dan lainlain seperti Instagram dan Youtube.

4. Situs jejaring sosial, di mana user memperoleh izin untuk terkoneksi dengan cara membuat informasi yang bersifat pribadi, kelompok atau sosial sehingga dapat terhubung atau diakses oleh orang lain, seperti misalnya Facebook.

5. Virtual game world, di mana pengguna melalui aplikasi 3D dapat muncul dalam wujud avatar-avatar sesuai keinginan dan kemudian berinteraksi dengan orang lain yang mengambil wujud avatar juga layaknya di dunia nyata, seperti online game.

6. Virtual social world, merupakan aplikasi berwujud dunia virtual yang memberi kesempatan pada penggunanya berada dan hidup di dunia virtual untuk berinteraksi dengan yang lain. Virtual social world ini tidak jauh berbeda dengan virtual game world, namun lebih bebas terkait dengan berbagai aspek kehidupan, seperti Second Life.

\section{Fungsi Media Sosial}

Media sosial umumnya dapat digunakan untuk saling berbagi infromasi. Tak jarang, media sosial juga digunakan sebagai sarana untuk melakukan interaksi sosial. Puntoadi (2011) mengemukakan media sosial mempunyai fungsi antara lain:

1. Membangun personal branding lewat sosial media merupakan tidak mengenal trik atau popularitas semu, karena audience yang akan menentukan.

2. Memberikan suatu kesempatan yang fungsinya interaksi lebih dekat dengan konsumen. Media sosial menawarkan content komunikasi yang lebih individual. 
Sedangkan fungsi media sosial dikemukakan Tenia (2017), sebagai berikut:

1. Mencari berita, informasi dan pengetahuan.

2. Mendapatkan hiburan dengan bermain media sosial.

3. Komunikasi online dinilai lebih efektif dan efisien.

4. Menggerakan masyarakat sebagai salah satu upaya untuk menanggapi berbagai masalah tersebut adalah dengan memberikan kritikan, saran, celaan hingga pembelaan melalui media sosial.

5. Sarana berbagi informasi yang bermanfaat bagi banyak orang, dari satu orang ke banyak orang lainnya.

\section{Media pembelajaran}

Menurut Yudhi Munadi (2013), media pembelajaran adalah segala sesuatu yang dapat menyampaikan dan menyalurkan pesan dari sumber secara tersistematis sehingga tercipta lingkungan belajar yang kondusif dimana peserta dapat melakukan proses belajar secara efisien dan efektif.

Gagne dan Briggs secara implisit mengatakan bahwa media pembelajaran meliputi alat yang secara fisik digunakan untuk menyampaikan isi materi pengajaran, yang terdiri dari buku, taperecorder, kaset, video camera, film, slide, foto, gambar, grafik, dan komputer. Dengan kata lain media adalah komponen sumber belajar atau wahana fisik yang mengandung materi instruksional di lingkungan siswa yang dapat merangsang siswa untuk belajar (Sudarman, 2010).

Sadiman (2009) media pembelajaran adalah segala sesuatu yang dapat digunakan untuk menyalurkan pesan dari pengirim ke penerima sehingga dapat memberikan stimulus pada pikiran, perasaan, perhatian dan minat serta perhatian siswa sedemikian rupa sehingga proses belajar terjadi.

Penggunaan media pembelajaran dapat membantu meningkatkan pemahaman dan daya serap siswa terhadap materi pelajaran yang dipelajari. Menurut Asnawir dan Usman (2002), fungsi-fungsi dari penggunaan media pembelajaran diantaranya:

1. Membantu memudahkan belajar bagi siswa dan membantu memudahkan mengajar bagi guru.

2. Memberikan pengalaman lebih nyata (yang abstrak dapat menjadi lebih konkrit)

3. Menarik perhatian siswa lebih besar (kegiatan pembelajaran dapat berjalan lebih menyenangkan dan tidak membosankan).

4. Semua indra siswa dapat diaktifkan.

5. Lebih menarik perhatian dan minat murid dalam belajar

Gagne \& Briggs dalam Arsyad (2002) mengemukakan bahwa media pembelajaran meliputi alat yang secara fisik digunakan untuk menyampaikan isi materi pembelajaran yang terdiri dari, antara lain: buku, tape-recorder, kaset, video kamera, video recorder, film, slide (gambarbingkai), foto, gambar, grafik, televisi, dan komputer. Berikut ini akan diuraikan klasifikasi Media Pembelajaran menurut taksonomi Leshin, dkk., dalam (Arsyad, 2008), yaitu:

1. Media berbasis manusia. Media berbasis manusia merupakan media yang digunakan untuk mengirimkan dan mengkomunikasikan pesan atau informasi. Media ini bermanfaat khususnya bila tujuan kita adalah mengubah sikap atau ingin secara langsung terlibat dengan pemantauan pembelajaran.

2. Media berbasis cetakan. Media pembelajaran berbasis cetakan yang paling umun dikenal adalah buku teks, buku penuntun, buku kerja/latihan, jurnal, majalah, dan lembar lepas.

3. Media berbasis visual. Media berbasis visual (image atau perumpamaan) memegang peranan yang sangat penting dalam proses belajar. Media visual dapat memperlancar pemahaman dan memperkuat ingatan. Visual dapat pula menumbuhkan minat siswa dan dapat memberikan hubungan antara isi materi pelajaran dengan dunia nyata.

4. Media berbasis Audio-visual. Media visual yang menggabungkan 
penggunaan suara memerlukan pekerjaan tambahan untuk memproduksinya. Salah satu pekerjaan penting yang diperlukan dalam media audio-visual adalah penulisan naskah dan storyboard yang memerlukan persiapan yang banyak, rancangan, dan penelitian. Contoh media yang berbasis audio-visual adalah video, film, slide bersama tape, televisi.

5. Media berbasis komputer. Dewasa ini komputer memiliki fungsi yang berbeda-beda dalam bidang pendidikan dan latihan. Komputer berperan sebagai manajer dalam proses pembelajaran yang dikenal dengan nama Computer- Managed Instruction (CMI). Adapula peran komputer sebagai pembantu tambahan dalam belajar; pemanfaatannya meliputi penyajian informasi isi materi pelajaran, latihan, atau kedua-duanya. Modus ini dikenal sebagai ComputerAssisted Instruction (CAI). CAI mendukung pembelajaran dan pelatihan akan tetapi ia bukanlah penyampai utama materi pelajaran. Komputer dapat menyajikan informasi dan tahapan pembelajaran lainnya disampaikan bukan dengan media komputer.

\section{Media sosial dalam pembelajaran}

Perkembangan ilmu pengetahuan dan teknologi semakin canggih membuat semua hal terasa lebih cepat dan lebih mudah untuk diperoleh. Akses telekomunikasi dan transportasi mudah dan cepat juga harus diikuti dengan pengembangan sumber daya manusia. Agar tidak ketinggalan. Maka dalam menghadapi era yang serba digital kita dituntut harus selalu belajar dalam penggunaan perangkat teknologi. Salah satu yang semakin berkembang media sosial (medsos). Pilgrim \& Bledsoe (2011) mengungkapkan bahwa kekuatan dari media sosial pada era digital ini sangat luar biasa, sehingga media sosial seperti facebook sangat potensial dikembangkan untuk pembelajaran.
Menurut Couillard, C. (2009),

pemanfaatan media jejaring sosial seperti Facebook untuk mengakses media pembelajaran bukanlah hal baru dan telah diteliti efektifitasnya, serta pro dan kontranya. Senantiasa ada aspek pro dan kontra untuk sebuah inovasi, namun pemanfaatan facebook sebagai media pembelajaran adalah sebuah inovasi yang menantang.

Madge (2009) menyebutkan bahwa Facebook merupakan sarana potensial untuk menciptakan seatu pembelajaran yang efektif. Memanfaatkan facebook sebagai sarana untuk refleksi, sarana untuk memperoleh umpan baik dari mitra bestari, dan sarana untuk berkolaborasi dalam pembelajaran. Aspek yang menarik dari facebook adalah banyak anak muda yang mengenal baik dan pengguna setianya. Hal ini menunjukkan media social menjadi sebuah alternatif untuk melaksanakan pembelajaran kolaboratif di era digital.

\section{Evaluasi Pembelajaran}

Tujuan melakukan evaluasi pembelajaran secara umum adalah untuk mengetahui tingkat kemajuan siswa maupun tingkat keberhasilan metode yang digunakan guru dalam proses pembealajaran. Dalam pelaksanan evaluasi, evaluator akan memperoleh hasil berupa angka atau poin. Menurut Nana Sudjana (2009) tentang fungsi evaluasi dalam pendidikan dan pengajaran adalah sebagai berikut:

1. Alat untuk mengetahui tercapaitidaknya tujuan instruksional. Dengan fungsi ini maka penilaian harus mengacu pada rumusan-rumusan tujuan instruksional.

2. Umpan balik bagi perbaikan proses belajar-mengajar. Perbaikan mungkin dilakukan dalam hal tujuan instruksional, kegiatan belajar peserta didik, strategi belajar peserta didik, dll.

3. Dasar dalam penyusunan laporan kemajuan belajar siswa kepada orang tuanya.

Menurut Ngalim Purwanto (2009), menjelaskan ada dua macam evaluasi yaitu evaluasi formatif dan evaluasi sumatif. Model evaluasi ini, mengacu pada prinsip 
evaluasi model Tyler yakni mengetahui hasil belajar siswa sesuai dengan tujuan yang ditetapkan :

1. Evaluasi Formatif. Evaluasi formatif adalah evaluasi yang dilakukan pada setiap akhir pembahasan suatu pokok bahasan atau topik, dan dimaksudkan untuk mengetahui sejauh manakah suatu proses pembelajaran telah berjalan sebagaimana yang direncanakan. Evaluasi formatif adalah kegiatan menilai yang bertujuan untuk mencari umpan balik (feedback), selanjutnya hasil penilaian tersebut dapat digunakan untuk memperbaiki proses belajar mengajar yang sedang atau yang sudah dilaksanakan. Tes formatif ini bisa dilaksankan di akhir setiap pembelajaran, yaitu dilaksanakan pada setiap kali satuan pelajaran atau sub pokok bahasan berakhir atau dapat diselesaikan. Tes formatif ini biasa dikenal dengan istilah "Ulangan Harian". Dalam evaluasi formatif, juga memiliki fungsi utama, yaitu untuk mengetahui keberhasilan dan kegagalan proses belajar mengajar.

2. Evaluasi Sumatif. Istilah "sumatif" berasal dari kata "sum" yang berarti "total obtained by adding together item, numbers amounts". Artinya penilaian sumatif berarti penilaian yang dilakukan jika satuan pengalaman belajar atau seluruh materi pelajaran dianggap telah selesai. Dengan demikian, ujian akhir semester dan Ujian Nasional termasuk penilaian sumatif. Evaluasi sumatif adalah suatu penilaian yang pelaksanaannya itu dilakukan pada akhir semester dari akhir tahun. Jadi, tujuannya adalah untuk melihat hasil yang dicapai oleh para siswa.

\section{METODE PENELITIAN}

Metode penelitian yang digunakan adalah metode penelitian kuantitatif. Menurut Kasiram (2008), metode kuantitatif adalah suatu proses menemukan pengetahuan yang menggunakan data berupa angka sebagai alat menganalisis keterangan mengenai apa yang ingin diketahui.

\section{Lokasi dan waktu penelitian}

Lokasi penelitian dilakukan pada saat Pelatihan Dasar CPNS Kabupaten Halmahera Selatan Tahun 2020 bertempat di Hotel Ayu Lestari Ternate. Waktu penelitian dilaksanakan dari tanggal 22 sampai dengan 26 Februari 2020.

\section{Populasi dan Sampel}

Menurut Sukmadinata (2011) Populasi adalah kelompok besar dan wilayah yang menjadi lingkup penelitian kita. Sedangkan menurut Sabar (2010), sampel adalah sebagian dari subyek dalam populasi yang diteliti, yang sudah tentu mampu secara representatif dapat mewakili populasinya. Jumlah sampel dalam penelitian ini sebanyak 30 responden.

\section{Teknik pengumpulan data}

Teknik pengumpulan data yang digunakan dalam penelitian adalah kajian pustaka dan penyebaran kuisioner. Jenis kuisioner yang digunakan adalah kuisioner tertutup. Kuesioner disebarkan secara langsung kepada peserta pelatihan.

\section{Teknik analisis data}

Teknik analisa data dalam penelitian menggunakan metode statistik deskriptif. Menurut Sugiyono (2007), statistik deskriptif berfungsi untuk mendeskripsikan atau memberi gambaran terhadap objek yang diteliti melalui data sampel atau populasi.

\section{HASIL DAN PEMBAHASAN}

\section{Tahapan Penerapan Evaluasi Pembelajaran \\ Penerapan evaluasi pembelajaran} melalui media sosial Kahoot.it dan Facebook dilakukan dengan cara atau proses yang pertama Widyaiswara menyampaikan materi Mata Pelatihan Nasionalisme dengan menggunakan laptop dan LCD serta speaker. Metode pembelajaran yang digunakan adalah metode andragogi atau pembelajaran 
orang dewasa. Menurut Asmin (2005), pembelajaran orang dewasa bertujuan mengembangkan kemampuan, memperkaya pengetahuan, meningkatkan kualifikasi teknis, dan jiwa profesionalisme para peserta pelatihan. Singkatnya, kegiatan belajar sebagian besar berfokus pada peserta pelatihan.

Setelah itu, kedua membagi atau membentuk peserta menjadi 5 kelompok diskusi berbasis kesetaraan gender. Pembagian kelompok berdasarkan kesetaraan gender dimaksudkan agar semua peserta memiliki kesempatan yang sama dalam bertukar pikiran dan menyampaikan gagasan pada saat diskusi.

Ketiga, peserta lastar melakukan diskusi kelompok (DISKO) tentang materi Nasionalisme. Peserta diberikan kesempatan melakukan diskusi kelompok selama 3 Jam pelajaran dengan tema pemabahasan yang telah ditentukan. Hasil diskusi kelompok dituangkan dalam power point.

Keempat, peserta mempresentasikan hasil diskusi sesuai tema yang telah ditetapkan setiap kelompok. Peserta diberikan kesempatan masing-masing kelompok 30 menit, dimana 10 menit untuk mempresentasikan sedangkan 20 menit untuk menanggapi pertanyaan dan masukan dari kelompok lain.

Selanjutnya kelima, fasilitator menjelaskan metode evaluasi pembelajaran menggunakan aplikasi Kahoot.it dan Facebook. Peserta diminta memperhatikan cara mengerjakan evaluasi pembelajaran, sehingga dalam pelaksanaan bisa berjalan dengan lancar.

Setelah peserta telah memahami cara evaluasi menggunakan Kahoot.it maka langkah keenam, Widyaiswara memulai melaksanakan evaluasi pembelajaran menggunakan aplikasi Kahoot.it. Pelaksanaan evaluasi dengan 10 pertanyaan dan masing-masing soal diberikan waktu menjawab selama 30 detik.

Selesai melakukan evaluasi pembelajaran menggunakan aplikasi Kahoot.it, langkah ketujuh adalah Widyaiswara meminta peserta menuliskan pemahaman tentang materi Nasionalisme yang telah dipelajari di dinding Facebook masing-masing peserta dengan dengan bahasa yang mudah dipahami. Setiap peserta wajib menuliskan hashtag \#Nasionalisme \#LatsarCPNSHalsel2 \#TaufikZK, sebagai kode untuk Widyaiswara dapat melacak postingan masing-masing peserta.

Cara refleksi materi atau mendalami materi yang telah dipelajari menggunakan facebook bertujuan memberikan kesempatan kepada peserta mengulangi materi yang telah dipelajari agar mudah diingat kembali. Selain itu, dapat menyebarkan informasi positif di media sosial dan menjadi pengingat otomatis setiap tahun tentang proses pembelajaran yang telah dilaluinya. Lebih jelas dapat lihat gambar 1 Pelaksanaan Evaluasi Pemahaman di Facebook.

Setelah tahapan evaluasi telah dilakukan, maka langkah terakhir atau kedelapan adalah meminta peserta 
menyampaikan testimony secara tertulis tentang pelaksanaan evaluasi pembelajaran. Lebih jelasnya dapat lihat gambar 4. Testimony Peserta Pelatihan.

Hasil dari testimony, rerata peserta sangat senang dengan metode yang digunakan, aplikasi yang mudah digunakan, kreatif, berbasis pemanfaatan teknologi serta menambah semangat belajar.

\section{Implementasi Evaluasi Pembelajaran Berbasis Media Sosial}

Berdasarkan hasil penelitian evaluasi pembelajaran berbasis media sosial diketahui bahwa penyebaran kuesioner menggambarkan persepsi responden terhadap proses pembelajaran mata pelatihan Nasionalisme Pelatihan Dasar CPNS. Persepsi responden dinilai dengan menggunakan empat skala, yaitu sangat setuju (4), setuju (3), kurang setuju (2), dan tidak setuju (1). Berikut penjelasan distribusi jawaban responden.

Berdasarkan distribusi jawaban responden dari 10 (enam) pernyataan mendapatkan respon yang beragam dari peserta pelatihan. Pernyataan pertama, penggunaan media evaluasi (Kahoot.it dan facebook) sangat kreatif dan inovatif. Maka jawaban responden sangat setuju sebesar $86.67 \%$, setuju sebesar $10 \%$, dan kurang setuju sebesar $3.33 \%$. Jadi, pemanfaatn teknologi dalam pembelajaran sangat diperlukan untuk menumbuhkan semangat kreatifitas dan inovasi dikalangan peserta pelatihan, tentunya penggunaan teknologi memperhatikan aplikasi yang mudah dioperasikan dan langsung mengetahui hasil belajarnya.

Pernyataan kedua, penggunaan media evaluasi pembelajaran (Kahoot.it dan Facebook) sudah Efektif dan efisien. Maka diketahui bahwa responden yang memilih sangat setuju sebesar $63.33 \%$ dan setuju sebesar $36.67 \%$. Jadi, penggunaan aplikasi Kahoot.it dan Facebook dapat diterapkan dalam evaluasi pembelajaran.

Pernyataan ketiga, ketepatan pemilihan jenis aplikasi/software/tool (Kahoot.it dan Facebook) untuk evaluasi pembelajaran. Maka diketahui, responden yang memilih sangat setuju sebesar
$53.33 \%$, setuju sebesar 43.33 dan kurang setuju sebesar 3.33\%.

Pernyataan keempat, Selama proses evaluasi pembelajaran aplikasi berjalan dengan baik (reliable). Distribusi jawaban responden sangat setuju sebesar $40 \%$, setuju sebesar 56.67 dan kurang setuju sebesar 3.33. Jadi, dalam pelaksanaan evaluasi menggunakan Kahoot.it dan Facebook sangat bergantung dengan jaringan internet, semakin bagus jaringan internet, semakin bagus berjalannya evaluasi pembelajaran.

Pernyataan kelima, program atau aplikasi mudah digunakan atau dioperasikan (Usabilitas). Maka diketahui distribusi jawaban responden yang memilih sangat setuju sebesar $80 \%$ dan setuju sebesar $20 \%$.

Pernyataan keenam, dengan menggunakan aplikasi Kahoot.it dan Facebook saya dapat memperoleh pengalaman baru dalam proses evaluasi pembelajaran. Maka diketahui distribusi jawaban responden yang memilih sangat setuju sebesar $83.33 \%$, setuju sebesar $13.33 \%$ dan kurang setuju sebesar 3.33\%. Ini menunjukkan bahwa sebagian peserta sebelumnya belum mengetahui teknik evaluasi memanfaatkan teknologi.

Selanjutnya pernyataan ketujuh, soal dan Jawaban yang disajikan dalam evaluasi pembelajaran dapat dibaca dengan mudah. Maka diketahui distribusi jawaban responden memilih sangat setuju sebesar $66.67 \%$, setuju sebesar $30 \%$ dan kurang setuju sebesar 3.33\%.

Berikutnya pernyataan kedelapan mengenai eserta dapat memahami materi melalui media evaluasi pembelajaran Kahoot.it dan Facebook. Maka diketahui jawaban responden yang memilih sangat setuju sebesar $46.67 \%$, setuju sebesar $43.33 \%$ dan kurang setuju sebesar $10 \%$. Jadi, diketahui bahwa sebagian besar responden telah menyetujui bahwa peserta dapat memahami dan mendalami materi melalui evaluasi pembelajaran.

Selanjutnya pernyataan kesembilan, peserta termotivasi lebih rajin belajar setelah diberikan evaluasi pembelajaran menggunakan Kahoot.it dan Facebook. Maka diketahui distribusi jawaban 
Tabel 1. Distirbusi Jawaban Responden Tentang Evaluasi Pembelajaran

\begin{tabular}{|c|l|c|c|c|c||}
\hline No & \multicolumn{1}{|c|}{ Pernyataan } & $\mathbf{4}$ & $\mathbf{3}$ & $\mathbf{2}$ & $\mathbf{1}$ \\
\cline { 4 - 6 } & \multicolumn{1}{|c|}{$\begin{array}{l}\text { Penggunaan media evaluasi (Kahoot.it dan Facebook) } \\
\text { sangat kreatif dan inovatif }\end{array}$} & 86,67 & 10,00 & 3,33 & 0,00 \\
\hline 2 & $\begin{array}{l}\text { Penggunaan media evaluasi pembelajaran (Kahoot.it dan } \\
\text { Facebook) sudah Efektif dan efisien }\end{array}$ & 63,33 & 36,67 & 0,00 & 0,00 \\
\hline 3 & $\begin{array}{l}\text { Ketepatan pemilihan jenis aplikasi/software/tool } \\
\text { (Kahoot.it dan Facebook) untuk evaluasi pembelajaran }\end{array}$ & 53,33 & 43,33 & 3,33 & 0,00 \\
\hline 4 & $\begin{array}{l}\text { Selama proses evaluasi pembelajaran aplikasi berjalan } \\
\text { dengan baik (reliable). }\end{array}$ & 40,00 & 56,67 & 3,33 & 0,00 \\
\hline 5 & $\begin{array}{l}\text { Program atau aplikasi mudah digunakan atau } \\
\text { dioperasikan (Usabilitas) }\end{array}$ & 80,00 & 20,00 & 0,00 & 0,00 \\
\hline 6 & $\begin{array}{l}\text { Dengan menggunakan aplikasi Kahoot.it dan Facebook } \\
\text { saya dapat memperoleh pengalaman baru dalam proses } \\
\text { evaluasi pembelajaran }\end{array}$ & 83,33 & 13,33 & 3,33 & 0,00 \\
\hline 7 & $\begin{array}{l}\text { Soal dan Jawaban yang disajikan dalam evaluasi } \\
\text { pembelajaran dapat dibaca dengan mudah }\end{array}$ & 66,67 & 30,00 & 3,33 & 0,00 \\
\hline 8 & $\begin{array}{l}\text { Peserta dapat memahami materi melalui media evaluasi } \\
\text { pembelajaran Kahoot.it dan Facebook }\end{array}$ & 46,67 & 43,33 & 10,00 & 0,00 \\
\hline 9 & $\begin{array}{l}\text { Peserta termotivasi lebih rajin belajar setelah diberikan } \\
\text { evaluasi pembelajaran menggunakan Kahoot.it dan } \\
\text { Facebook }\end{array}$ & 73,33 & 26,67 & 0,00 & 0,00 \\
\hline 10 & $\begin{array}{l}\text { Penggunaan aplikasi Kahoot.it dan Facebook } \\
\text { memudahkan pengelolaan dokumen hasil evaluasi } \\
\text { pembelajaran }\end{array}$ & 70,00 & 30,00 & 0,00 & 0,00 \\
\hline \hline
\end{tabular}

responden memilih sangat setuju sebesar $73.33 \%$ dan setuju sebesar $26.67 \%$. Fakta ini menunjukkan bahwa pemanfaatan teknologi dalam pembelajaran akan memberikan dampak positif karena peserta akan semakin termotivasi untuk terus belajar dan berkembang.

Pernyataan terakhir atau kesepuluh, Penggunaan aplikasi Kahoot.it dan Facebook memudahkan pengelolaan dokumen hasil evaluasi pembelajaran. Maka diketahui bahwa, responden memilih sangat setuju sebesar $70 \%$ dan setuju sebesar 30\%. Dimana, aplikasi yang digunakan langsung dapat mengetahui hasil belajar peserta pelatihan serta memudahkan Widyaiswara dalam memberikan penilaian. Lebih jelasnya dapat lihat tabel 1. Distribusi jawaban responden tentang evaluasi pembelajaran.

Dengan demikian, maka dapat dijelaskan bahwa adanya sentuhan atau pemanfaatan teknologi di era yang serba digital mampu memberikan dampak positif sehingga sangat berpotensi untuk dikembangkan dalam proses pembelajaran.
Pemanfaatan Kahoot.it dan Facebook sebagai media evaluasi pembelajaran merupakan salah satu inovasi pembelajaran kolaboratif di era digital.

\section{PENUTUP}

\section{Kesimpulan}

Berdasarkan hasil pembahasan penelitian maka dapat disimpulkan diantaranya:

1. Penerapan evaluasi pembelajaran dimulai dengan cara atau proses sebagai berikut yang pertama Widyaiswara menyampaikan materi mata pelatihan Nasionalisme. Kedua, membagi paserta kedalam 5 kelompok berbasis kesetaraan gender. Ketiga, peserta melakukan diskusi kelompok (Disko). Keempat, peserta mempresentasikan hasil diskusi secara bergantian. Kelima, Fasilitator menjelaskan metode evaluasi pembelajaran menggunakan Kahoot.it dan facebook. Keenam, Widyaiswara memulai melaksanakan evaluasi 
pembelajaran. Dan ketujuh, peserta diminta menuliskan tentang pemahaman materi yang telah dipelajari pada dindiing facebook miliknya.

2. Implementasi pemanfataan teknologi dalam evaluasi pembelajaran seperti Kahoot.it dan facebook memberikan dampak positif dalam proses pembelajaran. Dimana, Widyaiswara telah mampu beradaptasi dengan tuntutan zaman yang serba digital. Selain itu, peserta juga mendapatkan pengalaman baru dalam melaksanakan pembelajaran. Proses evaluasi dinilai sangat kreatif dan inovatif.

\section{Saran}

Berdasarkan hasil penelitian, maka saran yang dapat disampaikan adalah sebagai berikut:

1. Perlu dikembangkan aplikasi evaluasi pembelajaran secara mandiri.

2. Widyaiswara perlu melakukan Pengembangan kompetensi tentang pemanfaatan teknologi dalam pembelajaran.

\section{DAFTAR PUSTAKA}

Antony, Mayfield. 2008. What Is Sosial Media. ICrossing.

Arief S. Sadiman, dkk. 2009. Media Pendidikan, Pengertian, Pengembangan, dan Pemanfaatannya. Jakarta: Rajawali Press.

Arsyad, Azhar. 2002. Media Pembelajaran, edisi 1. Jakarta: PT. Raja Grafindo Persada.

$$
\text { 2008. Media }
$$

Pembelajaran. Jakarta: PT Raya Grafindo Persada

Asmin. 2005. Konsep dan Metode Pembelajaran Untuk Orang Dewasa (Andragogi). Psikologinet.com

Asnawir, Usman Basyiruddin. 2002. Media Pembelajaran, Jakarta: Ciputat Pers

Couillard, C. 2009. Facebook: The Pros and Cons of use in Education. Thesis,
University of Wisconsin-Stout: tidak diterbitkan.

Hanna, R., Rohm, A., \& Crittenden, V.L. 2011. We're all connected: The power of the social media ecosystem. Business horizons.

Hemsley, J., \& Mason, R.M. 2013. Knowledge and knowledge management in the social media age. Journal of Organizational Computing and Electronic Commerce.

Hidayati, Nurul dan Fidiana. 2017. Pengaruh Corporate Social Responsibility dan Good Corporate Governance terhadap Penghindaran Pajak. Jurnal Ilmu dan Riset Akuntansi. Volume 6, Nomor 3: 1052-1070. Surabaya: Sekolah Tinggi Ilmu Ekonomi Indonesia (STIESIA) Surabaya.

Kasiram, Moh. 2008. Metodologi Penelitian. Malang: UIN-Malang Pers.

Madge, C., Meek, J., Wellens, J., \& Hooley, T. 2009. Facebook, social integration and informal learning at university: 'It is more for socialising and talking to friends about work than for actually doing work'. Learning, Media and Technology

Mao, H., Liu, S., Zhang, J., \& Deng, Z. 2016. Information technology resource, knowledge management capability, and competitive advantage: the moderating role of resource commitment. International Journal of Information Management.

Michael Haenlein, 2010. Users of the world, unite! The challenges and opportunities of Social Media". Business Horizons

Munadi, Yudhi. 2013. Media Pembelajaran: Sebuah Pendekatan Baru. Jakarta: Referensi.

Nana Sudjana. 2009. Penilaian Hasil Proses Belajar Mengajar. Bandung: PT. 
Remaja Rosdakarya.

Ngafifi, Muhammad. 2014. Kemajuan teknologi dan pola hidup manusia dalam prespektif social budaya. Jurnal perkembangan pendidikan: fondasi dan aplikasi.

Ngalim Purwanto. 2009. Evaluasi Hasil Belajar. Yogyakarta: Pustaka Pelajar

Pakuningjati, Anindita Lintang. 2015. Pengelolaan Media Sosial Dalam Mewujudkan Good Governance. Skripsi : Universitas Gadjah Mada

Peraturan Lembaga Administrasi Negara Republik Indonesia. 2018, No. 12. Pelatihan Dasar Calon Pegawai Negeri Sipil.

Pilgrim, J., \& Bledsoe, C. 2011. Learning through facebook: A potential tool for educators. Delta Kappa Gamma Bulletin

Puntoadi, Danis. 2011. Meningkatkan penjualan melalui media sosial. Jakarta: PT. Gramedia Pustaka Utama.

Rutoto, Sabar. 2007. Pengantar Metedologi Penelitian. FKIP: Universitas Muria Kudus.

Sudarman, Denim. 2010. Media Komunikasi Pendidikan. Jakarta: Bumi Aksara

Sugiyono. 2010. Metode penelitian pendidikan pendekatan kuantitatif dan kualitatif dan R\&D. Bandung: Alfabeta.

Sukmadinata, N.S. 2011. Metode Penelitian Pendidikan. Bandung: Remaja Rosadakarya.

Tim Pusat Humas Kementerian Perdagangan RI. 2014. Panduan Optimalisasi Media Sosial Untuk Kemantrian Perdagangan RI, (Jakarta: Pusat Humas Kementerian Perdagangan RI

Tenia, H. 2017. Pengertian Media Sosial. Undang-Undang. 2014, No. 5. Aparatur Sipil Negara.

Veithzal Rivai. 2007. Bank and Financial Institute Management. Jakarta: PT. Raja Grafindo Persada. 
